\title{
Comparison of Silorane and Methacrylate-Based Composite Resins on the Curing Light Transmission
}

\author{
Ricardo Danil GUIRALDO ${ }^{1}$ \\ Simonides CONSANI ${ }^{2}$ \\ Rafael Leonardo Xediek CONSANI ${ }^{3}$ \\ Sandrine Bittencourt BERGER ${ }^{1}$ \\ Wilson Batista MENDES ${ }^{4}$ \\ Mário Alexandre Coelho SINHORETI ${ }^{2}$ \\ Lourenço CORRER-SOBRINHO ${ }^{2}$
}

\author{
${ }^{1}$ Department of Restorative Dentistry, School of Dentistry, University of North Paraná, Londrina, PR, Brazil \\ ${ }^{2}$ Department of Restorative Dentistry, Piracicaba Dental School, University of Campinas, Piracicaba, SP, Brazil \\ ${ }^{3}$ Department of Prosthodontics and Periodontics, Piracicaba Dental School, \\ University of Campinas, Piracicaba, SP, Brazil \\ ${ }^{4}$ Prosthodontics Graduate Program, Pythagoras College, Belo Horizonte, MG, Brazil
}

\begin{abstract}
The aim of this study was to investigate the influence of different composite resins - Filtek P90 (silorane-based composite) and Heliomolar (methacrylate-based composite) - on light transmission and decrease in Knoop hardness between the bottom and top of cured specimens. The irradiance of a light-curing unit (LCU) was measured with a power meter (Ophir Optronics; $\left.900 \mathrm{mw} / \mathrm{cm}^{2}\right)$ and spectral distributions were obtained using a spectrometer (USB 2000). Twenty standardized cylindrical specimens ( $2 \mathrm{~mm}$ thick x $7 \mathrm{~mm}$ diameter) of each composite resin were obtained by curing using the LCU for $40 \mathrm{~s}$. Light energy transmission through the composite was calculated $(n=10)$. The Knoop hardness number for each surface was recorded as the mean of 3 indentations. The difference in Knoop hardness between the top and bottom $(\mathrm{DKH})$ of the same specimen was calculated $(\mathrm{n}=10)$. The irradiance of light that passed through Filtek P90 $\left(272 \mathrm{~mW} / \mathrm{cm}^{2}\right)$ was not significantly greater than that the passed through Heliomolar $\left(271 \mathrm{~mW} / \mathrm{cm}^{2}\right)$. The DKH of Filtek P90 (25\%) was significantly higher than that of Heliomolar (12\%). There was a greater degree of subsurface polymerization of the methacrylate-based composite compared to the silorane-based composite.
\end{abstract}

Key Words: silorane-based composite, methacrylate-based composite, light transmission, Knoop hardness.

\section{INTRODUCTION}

The restorative composite resins have undergone continuous development during the most recent decades (1). Composite formulations have continued to evolve since bisphenol A glycidyl methacrylate (Bis-GMA) was first introduced to dentistry by Bowen in 1962 (2), and have been modified in various ways based on different properties, like viscosity or polarity. These changes were produced by variations of functional groups. Different co-monomers, such as triethylene glycol dimethacrylate (TEGDMA) and urethane dimethacrylate (UDMA), have been developed over time and contributed, in very different ways, to the profile of contemporary composites (1).
Currently, all commercially available composite resins have their common basis in the radical polymerization of methacrylates (1). These materials are composed of an organic matrix, load particles (glass, quartz and/or melted silica) and a bonding agent, usually an organic silane, that has a dual characteristic, enabling chemical bonding with the load particle and co-polymerization with the monomers of the organic matrix (3). The development of different composite resins has lead to remarkable improvements in terms of physical strength, wear resistance, and stability in the oral environment. Modern composites exhibit excellent physical resistance and esthetics. However, two major properties of composites that still have to be improved are polymerization shrinkage and the related

Correspondence: Prof. Dr. Ricardo Danil Guiraldo, Faculdade de Odontologia, UNOPAR, Rua Marselha, 183, 86041-140 Londrina, PR, Brasil. Tel: +55-43-3371-7820. Fax: +55-43-3341-8122. e-mail: rdguiraldo@gmail.com 
polymerization stress (1).

The amount of light available to excite the photoinitiator dramatically decreases from the top of the surface inward as a result of light absorption and scattering (4) by the composite itself or by the surrounding tissues/materials (5). The degree of cure of light-activated composite resins has been recognized as important to the clinical success of these materials soon after these materials were introduced (6). The advantage of testing the composite using the Knoop hardness test is the correlation between Knoop hardness and the degree of monomer conversion (DC) (7). DC directly influences the mechanical properties of a composite resin (7). Thus, after light curing, it is desirable to activate this restorative material in order to attain the best mechanical properties, and to convert all the monomer into polymer.

Moszner et al. (8) have reported that vinyl cyclopropane derivatives, such as radical curing ring opening monomers, are also able to copolymerize with common methacrylate-based resins. Adifferent chemical approach was used for this reaction, focusing on cationic ring opening of spiro ortho carbonates, especially in combination with epoxy monomers (1). Silorane, a low-shrinkage, tooth-colored restorative material, as claimed by the manufacturer, 3M ESPE, St. Paul, MN, USA, has been recently introduced to the market. Silorane was so named to indicate a hybrid compound of siloxane and oxirane functional moieties (9). While the siloxane determines the highly hydrophobic nature of the siloranes, the cycloaliphatic oxirane functional groups are responsible for lower shrinkage when compared to methacrylate-based composites. Oxiranes, which are cyclic ethers, polymerize by a cationic ring-opening mechanism, while methacrylates polymerize via a freeradical mechanism (1).

The aim of this study was to investigate the influence of different composite resins on light transmission and decrease in Knoop hardness between the bottom and top of cured specimens. The null hypothesis tested was that there is no difference in the decrease of Knoop hardness between bottom and top in silorane- and methacrylate-based composite resins.

\section{MATERIAL AND METHODS}

The restorative composite resins Filtek P90 (3M ESPE; shade A3) and Heliomolar (Ivoclar Vivadent, Schaan, Liechtenstein; shade A3) were used (Table 1).

Among the light-curing units (LCUs) available in the market, the most traditional ones use a quartz tungsten halogen (QTH) light (10). For this reason, we used a QTH lamp (XL 2500; 3M-ESPE) with irradiance of 900 $\mathrm{mw} / \mathrm{cm}^{2}$. The LCU output $(\mathrm{mW})$ was measured with a power meter (Ophir Optronics; Har-Hotzvim, Jerusalem, Israel). The tip diameter $(7 \mathrm{~mm})$ was measured with a digital caliper (model CD-15C; Mitutoyo, Tokyo, Japan) to determine the tip areas. The irradiance was calculated by dividing the light power by the tip area. The spectral distributions were obtained using a spectrometer (USB 2000; Ocean Optics, Dunedin, FL, USA).

Standardized cylindrical specimens were obtained by placing composite into the circular elastomer mold ( $2 \mathrm{~mm}$ thick $\times 7 \mathrm{~mm}$ diameter). The bottom and top surfaces were covered with a transparent polyester strip and photoactivated for $40 \mathrm{~s}$ in accordance with the manufacturers' recommendations. The LCU light-guide tip was positioned close to the elastomer mold/restorative composite set. Twenty specimens of each composite were fabricated with the dimensions of the elastomer mold.

\section{Light Energy Transmission Test}

Ten specimens of each material chosen at random were attached to the LCU light-guide tip with

Table 1. Information about the composites employed according to the manufacturers.

\begin{tabular}{|c|c|c|c|c|}
\hline Composite & Organic Matrix & Filler & Photo-initiator & Batch number \\
\hline Filtek P90 & Silorane resin & $\begin{array}{c}76 \% \text { by weight (mean: } 0.47 \mu \mathrm{m} \text { ) } \\
\text { quartz and yttrium fluoride }\end{array}$ & $\begin{array}{l}\text { Camphorquinone, } \\
\text { iodonium salt and } \\
\text { electron donor }\end{array}$ & $8 B L$ \\
\hline Heliomolar & $\begin{array}{l}\text { Bis-GMA, UDMA, } \\
\text { and 1,10-decanediol } \\
\text { dimethacrylate }\end{array}$ & $\begin{array}{c}66.7 \% \text { by weight (mean: } 0.04-0.2 \mu \mathrm{m} \text { ) } \\
\text { Silicon dioxide, ytterbium trifluoride } \\
\text { and copolymer }\end{array}$ & Camphorquinone & F58116 \\
\hline
\end{tabular}


black adhesive paper. The light that passed through the composite was measured with the power meter (Ophir Optronics) (10). The spectral distributions were obtained using a spectrometer (USB 2000; Ocean Optics). The irradiance data were subjected to ANOVA and the means were compared by the Student's t-test $(\alpha=0.05)$.

\section{Knoop Hardness Test}

After the photoactivation procedure, the other 10 specimens of each material were stored dry at $37^{\circ} \mathrm{C}$, for $24 \mathrm{~h}$. Thereafter, both the top and bottom surfaces were ground with \#200-, 400- and 600-grit $\mathrm{SiC}$ abrasive (Carborundum; Saint-Gobain Abrasives, Recife, PE, Brazil) to obtain polished, flat surfaces.

Indentations for Knoop hardness number (KHN) measurements were sequentially performed in a hardness testing machine (HMV 2; Shimadzu, Tokyo, Japan). Three readings were taken on the top and bottom surfaces under a load of $50 \mathrm{gf}$ for $15 \mathrm{~s}$ each. The KHN for each surface was recorded as the mean of the 3 indentations.

The difference in Knoop hardness between the top and bottom (DKH) surfaces was calculated for each specimen (10). The DKH data were subjected to ANOVA and the means were compared by the Student's t-test $(\alpha=0.05)$.

\section{RESULTS}

The amount of light (irradiance) $(\mathrm{p}>0.05)$ that passed through Filtek P90 $\left(272 \pm 7.8 \mathrm{~mW} / \mathrm{cm}^{2}\right)$ was not significantly greater compared to Heliomolar (271 $\pm 8.0 \mathrm{~mW} / \mathrm{cm}^{2}$ ).

Table 2 shows that the DKH of Filtek P90 was significantly $(25.84 \%)$ higher $(p<0.05)$ than that of

Table 2. Mean values of Knoop Hardness Number (KHN) and difference in Knoop hardness between the top and bottom (DKH) surfaces.

\begin{tabular}{lccc}
\hline \multirow{2}{*}{$\begin{array}{l}\text { Composite } \\
\text { resin }\end{array}$} & \multicolumn{2}{c}{ KHN } & \multirow{2}{*}{ DKH (\%) } \\
\cline { 2 - 3 } & Top & Bottom & \\
\hline Filtek P90 & $45.61(0.48)$ & $33.87(0.71)$ & $25.84(4.00) \mathrm{a}$ \\
Heliomolar & $33.18(0.30)$ & $28.91(0.24)$ & $12.85(0.98) \mathrm{b}$ \\
\hline
\end{tabular}

The values are expressed as means and standard deviations. Different letters indicate statistically significant difference (Student's t-test; $\mathrm{p}<0.05$ ).
Heliomolar (12.85\%). Figure 1 shows the wavelength distributions of the QTH LCU, and the light that passed through the specimens of both composite resins.

\section{DISCUSSION}

The tested null hypothesis was rejected, since differences were found in the decrease of Knoop hardness between the bottom and top surfaces of the silorane and methacrylate-based composite resins. Adequate polymerization is a crucial factor in obtaining an optimal physical mechanical performance of composite resins (11). A previous study indicated that factors such as filler and polymeric matrix refractive index, monomer type, filler type and filler content, can influence the light transmittance of composite resins (5). Hardness evaluation was used as an indirect method to verify the degree of conversion of composite resins (7).

During the photoactivation process, the light that passes through the resin composite is absorbed and scattered (12). Thus, the irradiance is attenuated and its effectiveness is reduced as the depth increases (13). Nevertheless, the polymerization depth depends on light irradiance, exposure time and several other factors namely material composition (14), composite shade (15) and translucency (16). All of these factors influence the amount of light (irradiance) that reaches the deepest layers of the material. If the amount of light is not sufficient, the degree of conversion in these areas

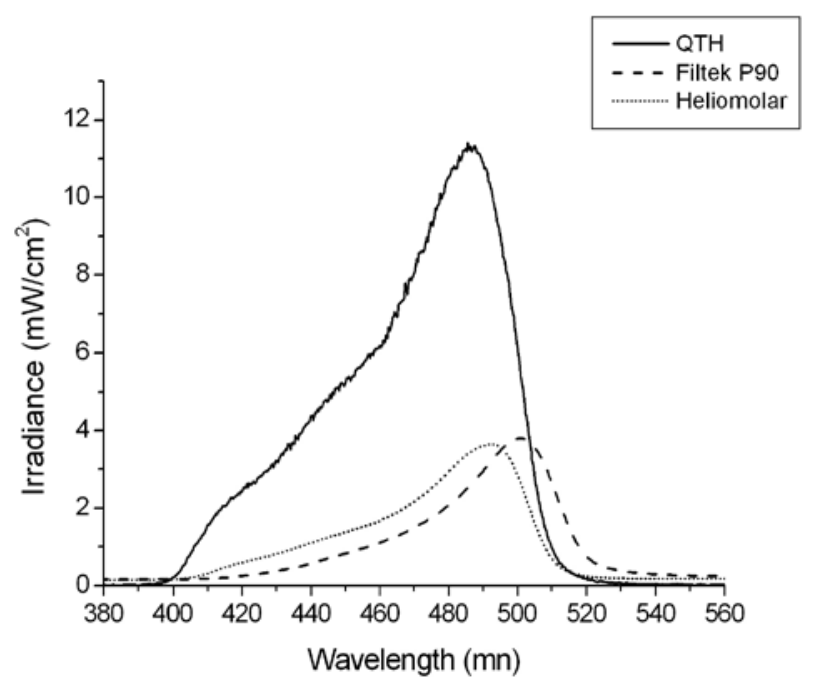

Figure 1. Wavelength distributions of the QTH LCU, and light irradiance that passed through the specimens of both composite resins. 
is low and the mechanical properties of the material, including Knoop hardness, are negatively affected. In the present study, the irradiance and the wavelength distributions (Fig. 1) that passed through the resin were similar between the composite resins.

The generation of radical species for methacrylate curing is produced using a two component system consisting of camphoroquinone, which is the actual photoinitiator, and a tertiary amine, responsible for the hydrogen transfer reaction (1). This system decomposes immediately due to exposure of light with a wavelength between 410 and $500 \mathrm{~nm}$, generating the radical species to start the polymerization process (17). The development of a photoactivated silorane-based composite occurs with a three component initiating system comprised of camphorquinone, iodonium salt and an electron donor. Camphorquinone was chosen as a photoinitiator to match the emission spectra of the currently used dental lamps. In this reaction path, the electron donor acts in a redox process and decomposes the iodonium salt into an acidic cation, which starts the ring opening polymerization process (1). It is beneficial to use non-coordinative counter-anions $\mathrm{A}^{-}$such as $\mathrm{SbF}_{6}$ - or $\mathrm{B}\left[\left(\mathrm{C}_{6} \mathrm{~F}_{5}\right)_{4}\right]^{-}$to enhance the reactivity. The 3 -component system provides the optimal balance between high polymerization reactivity and light stability (1). However, in the present study, deeper layers of Filtek P90 presented higher DKH than deeper layers of Heliomolar (Table 2).

Moreover, composite hardness is influenced by several factors, such as organic matrix composition, type and amount of filler particles and degree of conversion (18). In this study, the Knoop hardness of Filtek P90 was higher than that of Heliomolar. The organic matrix of Filtek P90 is composed mainly by silorane resin and the inorganic particles are quartz and yttrium fluoride ( $76 \%$ by weight). In contrast, the organic matrix of Heliomolar is composed mainly by Bis-GMA, UDMA and 1,10-decandiol dimethacrylate, and a combination of inorganic particles of silicon dioxide, ytterbium trifluoride and copolymer (66.7\% by weight). For this reason, the DKH was analyzed. The higher Knoop hardness means obtained for Filtek P90 may be explained by differences in the filler type and organic matrix composition between the materials (Table 1).

Undercured composite resin may present a large number of problems, such as poor color stability, greater staining, and a risk of pulp aggression by uncured monomers and portions of the material with different values of Young's modulus (19). It has been reported that loading well polymerized composite layers on poorly polymerized layers can lead the composite restoration to bend inward and displace, causing marginal fracture, open margins and cusp deflection (19). However, it has been suggested that a composite resin specimen has been adequately cured when there is no more than a $20 \%$ difference between the maximum hardness at the top of the composite and the maximum hardness at its bottom (20). According to these studies, it is speculated that in the present study, Filtek P90 did not present an efficient polymerization in deeper layers (Table 2). Under clinical conditions, it may be indicate to increase the exposure time in silorane-based composites, or use LCUs with greater irradiance than that of the halogen lamp used in the present study $\left(900 \mathrm{~mW} / \mathrm{cm}^{2}\right)$ to obtain better results. The irradiance must be sufficient to form free radicals and form polymers in both silorane and methacrylate-based composites. In summary, siloranebased composites are not as well polymerized below the surface as methacrylate-based composites.

Although this study was performed in vitro and thus have some limitations, the following conclusions can be drawn: 1. There was no difference in light transmission between silorane- and methacrylate-based composite resins; 2 . There was a greater degree of subsurface polymerization of the methacrylate-based composite compared to the silorane-based composite.

\section{RESUMO}

O objetivo deste estudo foi avaliar a influência da diferença entre a dureza do topo e da base em compósitos restauradores. Foram utilizados os compósitos restauradores Filtek P90 (compósito à base de silorano) e Heliomolar (compósito à base de metacrilato). A irradiância da unidade foto-ativadodora(UF) foi mensurada com um potenciômetro Ophir Optronics $\left(900 \mathrm{mw} / \mathrm{cm}^{2}\right)$ e o espectro de luz foi obtido usando um espectrofotômetro (USB 2000). Vinte espécimes cilíndricos padronizados ( $2 \mathrm{~mm}$ de espessura por 7 mm de diâmetro) foram obtidos pela fotoativação utilizando UF (40 s) para cada compósito. A irradiância que passou através do compósito foi mensurada $(\mathrm{n}=10)$. O número de dureza Knoop para cada superfície foi calculado pela média de 3 penetrações. A diferença da dureza Knoop entre o topo e base (DDK) de um mesmo espécime foi calculada $(n=10)$. A irradiância que passou através da Filtek P90 $\left(272 \mathrm{~mW} / \mathrm{cm}^{2}\right)$ não foi estatisticamente superior a Heliomolar $\left(271 \mathrm{~mW} / \mathrm{cm}^{2}\right)$. ADDK da Filtek P90 (25\%) foi estatisticamente superior a Heliomolar (12\%). O compósito a base de metacrilato apresentou melhor grau de polimerização na base quando comparado ao compósito à base de silorano.

\section{REFERENCES}

1. Weinmann W, Thalacher C, Guggenberger R. Siloranes in dental 
composites. Dent Mater 2005;21:68-78.

2. Bowen RL. Dental filling material comprising vinyl-silane treated fused silica and a binder consisting of the reaction product of bisphenol and glycidyl methacrylate. US Patent 3,066,112;1962.

3. Peutzfeldt A. Resin composites in dentistry: the monomer systems. Eur J Oral Sci 1997;105:97-116.

4. Rueggeberg FA, Caughman WF, Curtis JW JR, Davis HC. Factors affecting cure at depths within light-activated resin composites Am J Dent 1993;6:91-95.

5. Emami N, Sjödahl M, Soderhölm K-JM. How filler properties, filler fraction, sample thickness and light source affect light attenuation in particulate filled resin composites. Dent Mater 2005;21:721-730.

6. Ruyter IE, Oysaed H. Conversion in denture base polymers. J Biomed Mater Res 1982;16:741-754.

7. Ferracane JL. Correlation between hardness and degree conversion during the setting reaction of unfilled dental restorative resins. Dent Mater 1985;1:11-14.

8. Moszner N, Völkel T, Fischer U. Volker Polymerization of cyclic monomers, 8. Synthesis and radical polymerization of hybrid 2-vinylcyclopropanes Rheinberger. Macromol Rapid Commun 1999;20:33-35.

9. Navarra CO, Cadenaro M, Armstrong SR, Jessop J, Antoniolli F, Sergo V, et al.. Degree of conversion of Filtek Silorane Adhesive System and Clearfil SE Bond within the hybrid and adhesive layer: an in situ Raman analysis. Dent Mater 2009;25:1178-1185.

10. Guiraldo RD, Consani S, Consani RL, Berger SB, Mendes WB, Sinhoreti MAC. Light energy transmission through composite influenced by material shades. Bull Tokyo Dent Coll 2009;50:183190.

11. Dall'Magro E, Correr AB, Costa AR, Correr GM, Consani RLX, Correr-Sobrinho L, Sinhoreti MAC. Effect of different photoactivation techniques on the bond strength of a dental composite. Braz Dent J 2010;21:220-224.

12. Dos Santos GB, Monte Alto RV, Filho HR, da Silva EM, Fellows CE. Light transmission on dental resin composites. Dent Mater 2008;24:571-576.

13. Vargas MA, Cobb DS, Schmit JL. Polymerization of composite resins: argon laser vs conventional light. Oper Dent 1998;23:8793.

14. Atmadja G, Bryant RW. Some factors influencing the depth of cure of visible light-activated composite resins. Aust Dent J 1990;35:213-218.

15. Tanoue N, Koishi Y, Matsumura H, Atsuta M. Curing depth of different shades of a photo-actived prosthetic composite material. J Oral Rehabil 2001;28:618-623.

16. Ferracane JL, Aday P, Matsumura H, Atsuta M. Relationship between shade and depth of cure for light-activated dental composite resins. Dent Mater 1986;2:80-84.

17. Cook WD. Spectral distributions of dental photo-polymerization sources. J Dent Res 1982;61:1436-1438.

18. Correr AB, Sinhoreti MA, Sobrinho LC, Tango RN, Schneider LF, Consani S. Effect of the increase of energy density on Knoop hardness of dental composites light-cured by conventional QTH, LED and xenon plasma arc. Braz Dent J 2005;16:218-224.

19. Shortall AC, Wilson HJ, Harrington E. Depth of cure of radiationactivated composite restoratives influence of shade and opacity. J Oral Rehabil 1995;22:337-342.

20. Dunn WJ, Bush AC. A comparison of polymerization by lightemitting diode and halogen-based light-curing units. J Am Dent Assoc 2002;133:335-341.

Accepted November 16, 2010 